\title{
SPRAWY KOŚCIOŁA PRAWOSŁAWNEGO, KOŚCIOŁÓW EWANGELICKICH I GMIN WYZNANIOWYCH ŻYDOWSKICH W PRAKTYCE PRAWNEJ PROKURATORII GENERALNEJ RZECZYPOSPOLITEJ POLSKIEJ W LATACH 1919-1939
}

\section{WPROWADZENIE}

W Polsce okresu międzywojennego ochrona interesów prawnych i majątkowych państwa oraz innych podmiotów, traktowanych w zakresie ochrony prawnej na równi z państwem, została zorganizowana na zasadzie scentralizowanego systemuํ. W 1919 r. Józef Piłsudski, pełniący funkcję Tymczasowego Naczelnika Państwa, powołał Prokuratorię Generalną Rzeczypospolitej Polskiej, którą Sejm Ustawodawczy utrzymał w ustroju państwa $^{2}$. Prezesem Prokuratorii został Stanisław Bukowiecki ${ }^{3} \mathrm{~W}$ trakcie prac

DR HAB. MAREK TKACZuK - Wydział Prawa i Administracji, Uniwersytet Szczeciński; adres do korespondencji: ul. Narutowicza 17A, 70-240 Szczecin, Polska; e-mail: marek.tkaczuk@usz.edu.pl; https://orcid.org/0000-0001-9511-813x

${ }^{1}$ Sprawozdanie stenograficzne z 82 posiedzenia Sejmu Ustawodawczego z 31 lipca 1919 r. [dalej cyt.: Ss82SU] - LXXXII, Wystąpienie posła Ćwikowskiego, ł. 61-62.

${ }^{2}$ Dekret z dnia 7 lutego 1919 r. w przedmiocie utworzenia Prokuratorii Generalnej, Dz. Pr. P.P. Nr 14, poz. 181; ustawa z dnia 31 lipca 1919 r. w przedmiocie utworzenia Prokuratorii Generalnej Rzeczypospolitej Polskiej, Dz. U. Nr 75, poz. 390. Reorganizacja Prokuratorii oraz uporządkowanie jej kompetencji nastąpiło na mocy rozporządzenia Prezydenta Rzeczypospolitej z dnia 9 grudnia 1924 r. o zmianie ustroju Prokuratorii Generalnej Rzeczypospolitej Polskiej, Dz. U. Nr 107, poz. 967. Szerzej zob. Tkaczuk 2001, 152, 154-55; Organiściak 2002, 141-54; Tkaczuk 2006, 727; Tenże 2007, 285-301; Buczyński i Sosnowski 2016, 114, 120; Sitek 2020, 74.

${ }^{3}$ Archiwum Akt Nowych [dalej cyt.: AAN] - Kancelaria Cywilna Naczelnika Państwa, sygn. 64, k. 16, 19. 
komisji prawniczej Sejmu Ustawodawczego uznano, że zakres ochrony prawnej Prokuratorii w stosunku do rozwiązań dekretu Tymczasowego Naczelnika Państwa zostanie rozszerzony m.in. o „majątek kościelny”4. Propozycja komisji prawniczej dokonania zamiany dekretu $\mathrm{z}$ dnia 7 lutego 1919 r. na ustawę i modyfikację przepisów regulujących organizację i kompetencje Prokuratorii Generalnej stała w opozycji do stanowiska rządu, który nie planował w tej kwestii zmian ${ }^{5}$. Projekt ustawy w sprawie Prokuratorii był przedmiotem obrad sejmu na posiedzeniu w dniu 31 lipca 1919 r. ${ }^{6}$ Rada Ministrów projekt ustawy zmieniający organizację i zakres kompetencji Prokuratorii ostatecznie poparła i sejm ustawę uchwalił7. Prokuratorii Generalnej powierzono opiekę prawną interesów prawnych i majątkowych kościołów różnych wyznań. Państwo polskie poprzez Prokuratorię Generalną, tak jak w okresie zaborów czyniły to państwa zaborcze, przejęło kontrolę nad działalnością związków wyznaniowych w zakresie stosunków cywilnoprawnych w drodze obligatoryjnego zastępstwa prawnego [Krasowski 1988, 133-34; Sitek 2014, 255]. W stosunkach z kościołami Prokuratoria Generalna przede wszystkim chroniła interesy majątkowe Skarbu Państwa podejmując czynności zastępstwa prawnego albo wydając na żądanie władz państwowych opinie prawne. Zawarcie w 1925 r. konkordatu ze Stolicą Apostolską doprowadziło do uzyskania przez Kościół katolicki samodzielności w tego rodzaju stosunkach. Konsekwencją wejścia w życie konkordatu było uchylenie z dniem 1 stycznia 1926 r. ciążącego na Prokuratorii Generalnej obowiązku zastępstwa prawnego Kościoła katolickiego ${ }^{8}$. Na mocy tego samego rozporządzenia Rady Ministrów uchylono też

${ }^{4}$ Sejm Ustawodawczy Rzeczypospolitej Polskiej [dalej cyt.: SURP], druk nr 861, Sprawozdanie komisji prawniczej z dnia 19 lipca 1919 r. w sprawie dekretu z dn. 7 lutego 1919 r. (Dz. Pr. Nr 14 poz. 181) w przedmiocie utworzenia Prokuratorii Generalnej Rzeczypospolitej Polskiej, załącznik do druku, art. 3 ust. 8 projektu ustawy w przedmiocie utworzenia Prokuratorii Generalnej Rzeczypospolitej Polskiej, s. 3.

${ }^{5}$ AAN-Prezydium Rady Ministrów [dalej cyt.: PRM], sygn. 2/8/0/1.2/I 6, k. 432, mkf. 20050, Protokół z posiedzenia Rady Ministrów z dnia 19 maja 1919 r.; AAN-PRM, sygn. 56-15, Pismo Sekcji Legislacyjnej PRM do Prezesa Prokuratorii Generalnej $\mathrm{z}$ dnia 20 maja $1919 \mathrm{r}$.

${ }^{6}$ Ss82SU-LXXXII, ł. 1-2.

${ }^{7}$ Ss82SU-LXXXII, Wystąpienie Prezesa Prokuratorii Generalnej Bukowieckiego, jako przedstawiciela rządu, 1. 72; Wynik głosowania w sprawie ustawy o powołaniu Prokuratorii Generalnej, 1. 77.

${ }^{8}$ Rozporządzenie Rady Ministrów z dnia 16 grudnia 1925 r. o uchyleniu ciażacego na Prokuratorii Generalnej obowiąku zastępowania majątków kościelnych, Dz. U. Nr 127, poz. 904. 
obowiązek Prokuratorii Generalnej zastępstwa prawnego innych kościołów i wyznań religijnych oraz instytucji kościelnych ${ }^{9}$. Zniesienie państwowej opieki nad sprawami majątkowymi tych kościołów i związków wyznaniowych było podyktowane koniecznością urzeczywistnienia konstytucyjnej zasady równości wyznań i samodzielności kościołów w zakresie prowadzenia wewnętrznych spraw, w tym w szczególności o charakterze majątkowym [Krasowski 1988, 134] ${ }^{10}$. Od 1926 r. Prokuratoria Generalna w ramach agendy spraw wyznaniowych koncentrowała się na ochronie interesów prawnych i majątkowych państwa polskiego w relacjach z kościołami i związkami wyznaniowymi w drodze czynności opiniodawczych i zastępstwa prawnego.

\section{SPRAWY KOŚCIOŁA PRAWOSŁAWNEGO W POLSCE}

Obok spraw Kościoła katolickiego ${ }^{11}$, dominujących w agendzie wyznaniowej, licznego kontyngentu czynności dostarczały Prokuratorii Generalnej sprawy Kościoła prawosławnego (Cerkwi) w Polsce. Do najistotniejszych zagadnień absorbujących Prokuratorię należały kwestie osobowości prawnej Cerkwi oraz własności majątku nieruchomego pozostającego we władaniu prawosławnych instytutów, w szczególności w kontekście ustawy $\mathrm{z}$ dnia 17 grudnia 1920 r. o przejęciu na wtasność Państwa ziem w niektórych powiatach Rzeczypospolitej Polskiej ${ }^{12}$.

W 1920 r. analizując sprawę prawa własności soboru na placu Saskim w Warszawie Prokuratoria przedstawiła swoje stanowisko na temat osobowości prawnej Cerkwi w Rosji ${ }^{13}$. Zdaniem Prokuratorii Cerkiew nie miała

\footnotetext{
9 Tamże.

${ }^{10}$ Ustawa z dnia 17 marca 1921 r. Konstytucja Rzeczypospolitej Polskiej, Dz. U. Nr 44, poz. 267, art. 113 .

${ }^{11}$ Szerzej zob. Tkaczuk 2020, 515-31; Tenże 2006, 728-29.

${ }^{12}$ Dz. U. z 1921 r. Nr 4, poz. 17; Sprawozdanie Prezesa Prokuratorii Generalnej [dalej cyt.: SPPG] za rok 1933, s. 70. Sprawozdania Prezesa Prokuratorii Generalnej wykorzystane w artykule znajdują się m.in. w bibliotece b. Katedry Prawa Rzymskiego, Historii Prawa i Doktryn Polityczno-Prawnych na Wydziale Prawa i Administracji, Uniwersytet Szczeciński.

${ }^{13}$ AAN-Ministerstwo Wyznań Religijnych i Oświecenia Publicznego [dalej cyt.: MWRiOP], Majątki. Sprawy ogólne. Stan prawny majątku Kościoła prawosławnego w Polsce - opinie prawne i projekty ustaw 1920-1939, sygn. 2/14/0/5/1191, Odpis z odpisu pisma Prokuratorii Generalnej Rzeczypospolitej Polskiej z 3 września 1920 r.
} 
podmiotowości i była jedynie organem państwa rosyjskiego. Nie było rozdziału między państwem rosyjskim a Cerkwią, która była w pełni podległa władzy panującego. Konsekwencją tego stanu było uznanie przez Prokuratorię, że Cerkiew nie mogła być podmiotem własności jakichkolwiek rzeczy. Majątek, w który wyposażona była Cerkiew, stanowił własność Skarbu Państwa rosyjskiego, który przeszedł na Skarb Państwa polskiego ${ }^{14}$. W 1927 r. Prokuratoria Generalna sporządziła opinię dotyczącą uznania parafian w Kościele prawosławnym za zrzeszenie wiernych mogących być podmiotem prawa własności majątku kościelnego, w której ponownie rozważano kwestię osobowości prawnej Cerkwi ${ }^{15}$. Prokuratoria w dalszym ciągu stała na stanowisku, że Cerkiew nie była osobą prawną i była w jedni z państwem rosyjskim. Modyfikacją w tym stanowisku było jednak uznanie przez Prokuratorię, że parafie prawosławne, klasztory, opactwa, władze diecezjalne mogły być wyposażone w niektóre przymioty osób prawnych. Prokuratoria stanowczo odrzuciła możność uznania na gruncie prawa polskiego, że zrzeszenie wiernych mogło być podmiotem własności majątku instytutów Kościoła prawosławnego. W 1928 r. opierając się na analizie relacji Cerkwi do b. państwa rosyjskiego, interpretacji art. XII traktatu ryskiego oraz ust. 17 Tymczasowych przepisów o stosunku rzqdu do Kościoła prawostawnego $w$ Polsce z dnia 30 stycznia $1922 \mathrm{r}^{16}{ }^{16}$, uznając jednocześnie, że brak było ciągłości i sukcesji prawnej między Cerkwią rosyjską a polską ${ }^{17}$, Prokuratoria podtrzymała swoje stanowisko, iż majątki b. prawo-

Odpowiedź na pismo z 31 grudnia 1919 r. L.13216/1569 w sprawie tytułu własności b. Soboru na Placu Saskim i b. cerkwi pułku Litewskiego przy ul. Ujazdowskiej oraz placów pod temiż; kierowane do Ministerstwa Spraw Wojskowych, Sekcji Budownictwa Wojskowego, skan 41-52, zob. https://www.szukajwarchiwach.gov.pl/ [dostęp: 28.05. 2021]. Krytyczne stanowisko odnośnie opinii Prokuratorii z 3 września 1920 r. zajął K. Krasowski, zob. Krasowski 1988, 130-32.

${ }^{14}$ Tamże, skan 45, 52.

${ }^{15}$ AAN-MWRiOP, Majątki. Ziemie cerkiewne. Przejmowanie na własność państwa, sprzedaż, dzierżawa, przydział dla parafii, parcelacje. Sprawy ogólne, sygn. 2/14/0/5/ 1192, Pismo Prokuratorii Generalnej Rzeczypospolitej Polskiej z 25 lipca 1927 r. do Ministerstwa Wyznań Religijnych i Oświecenia Publicznego, skan 313-315, zob. https:// www.szukajwarchiwach.gov.pl/ [dostęp: 29.05.2021].

${ }^{16}$ Zarządzenie Ministra Wyznań Religijnych i Oświecenia Publicznego z dnia 30 stycznia 1922 r. Tymczasowe przepisy o stosunku Rzqdu do Kościoła Prawosławnego $w$ Polsce, M.P. Nr 38, poz. 20.

${ }^{17}$ AAN-MWRiOP, Majątki. Sprawy ogólne. Stan prawny majątku Kościoła prawosławnego w Polsce - opinie prawne i projekty ustaw 1920-1939, sygn. 2/14/0/5/1191, Odpis pisma Prokuratorii Generalnej Rzeczypospolitej Polskiej z dnia 18 marca 1928 r. 
sławnych instytutów cerkiewnych stanowią formalnie własność Skarbu Państwa do momentu, gdy w drodze ustawodawczej nie zostaną przekazane polskim instytutom prawosławnym ${ }^{18}$. W związku z pozostawieniem instytutom prawosławnym zarządu nieruchomościami Prokuratoria zwracała uwagę, że wynikające $\mathrm{z}$ rosyjskich przepisów ograniczenia w zarządzie tymże majątkiem pozostawały w mocy ${ }^{19}$.

Niejasna sytuacja prawna wyznania prawosławnego w Polsce powodowała, że Prokuratoria wielokrotnie apelowała do władz centralnych o podjęcie działań zmierzających do niezwłocznego uregulowania pozycji tej konfesji w drodze ustawodawczej ${ }^{20}$.

Na określenie pozycji prawnej Cerkwi prawosławnej w Polsce obok opinii Prokuratorii wpływ miało orzecznictwo Sądu Najwyższego. W dniu 2 czerwca 1931 r. Sąd Najwyższy wydał wyrok mający w tej materii zasadnicze znaczenie. Orzeczenie uznawało, że poszczególne instytuty prawosławne takie jak cerkwie czy monastyry na obszarze b. zaboru rosyjskiego miały osobowość prawną i majątek odrębny od Skarbu Państwa, autokefaliczność Cerkwi prawosławnej w Polsce była bez znaczenia dla oceny własności tych instytutów oraz że tymczasowe przepisy z dnia 30 stycznia $1922 \mathrm{r}$. o stosunku rządu do Cerkwi nie wprowadziły żadnej zmiany w kwestii własności i zarządu majątku sprawowanego przez Konsystorze ${ }^{21}$. Prokuratoria Generalna uznała orzeczenie Sądu Najwyższego za przeciwne zasadniczemu stanowisku, którego broniła od lat ${ }^{22}$. Wyrok Sądu Najwyższego spowodował także falę powództw przeciwko Skarbowi Państwa o zwrot nieruchomości cerkiewnych, w szczególności na Podlasiu i Chełmszczyźnie. Obrona Skarbu prowadzona przez Prokuratorię opierała się na argu-

do Ministerstwa Rolnictwa w sprawie dyspozycji prawami zapisanymi na rzecz probostwa w Szychowicach na dobrach Małków, Kryłów Porahoryłe w powiecie Hrubieszowskim, skan 80, zob. https://www.szukajwarchiwach.gov.pl/ [dostęp: 29.05.2021].

18 Tamże, skan 81; SPPG-1928, s. 62-63.

${ }^{19}$ SPPG-1929, s. 47.

${ }^{20}$ AAN-MWRiOP, Majątki. Sprawy ogólne. Stan prawny majątku Kościoła prawosławnego w Polsce - opinie prawne i projekty ustaw 1920-1939, sygn. 2/14/0/5/1191, Odpis pisma Prokuratorii Generalnej Rzeczypospolitej Polskiej z dnia 18 marca 1928 r. do Ministerstwa Rolnictwa w sprawie dyspozycji prawami zapisanymi na rzecz probostwa w Szychowicach na dobrach Małków, Kryłów Porahoryłe w powiecie Hrubieszowskim, skan 80, zob. https://www.szukajwarchiwach.gov.pl/ [dostęp: 29.05.2021]; SPPG-1931, s. 64.

${ }^{21}$ Wyrok Sądu Najwyższego z dnia 2 czerwca 1931 r., sygn. akt N.I.C. 47/31, w: SPPG-1931, s. 64.

${ }^{22}$ SPPG-1931, s. 64. 
mentacji, że zatrzymanie we władaniu Skarbu spornych nieruchomości umożliwiał dekret $\mathrm{z}$ dnia 16 grudnia 1918 r. w przedmiocie przymusowego zarzqdu państwowego ${ }^{23}$. Prokuratoria wzmacniała swoje stanowisko wyrokiem Sądu Najwyższego z dnia 9 października 1931 r., który wyrażał zapatrywanie prawne, że zarząd państwowy istniał ze wszystkimi konsekwencjami już od chwili ogłoszenia odpowiedniego zarządzenia w Monitorze Polskim i mianowania zarządcy, bez względu na to, czy przymusowy zarząd został faktycznie wprowadzony w życie oraz to, że już samo ogłoszenie ustanowienia zarządu nadawało państwu tytuł prawny do władania nieruchomością ${ }^{24}$. Odpierając powództwa instytutów prawosławnych Prokuratoria opierała obronę także na literalnej interpretacji wyroku Sądu Najwyższego z dnia 2 czerwca $1931 \mathrm{r}$. podnosząc, że zdolności sądowej nie miały instytuty niewymienione w wyroku, w szczególności parafie prawosławne ${ }^{25}$. Wskazywano także na brak zdolności procesowej Konsystorzy do działania w imieniu uznanych instytutów prawosławnych. Akcje Prokuratorii z zasady przynosiły skutek. Przykładowo w 1935 r. Urząd Główny Prokuratorii Generalnej doprowadził do umorzenia spraw wytoczonych przez Konsystorz Warszawsko-Chełmski w imieniu „Kościoła Prawosławnego w Polsce” o własność nieruchomości w Piotrkowie Trybunalskim ${ }^{26}$. Zdarzało się jednak, że Skarb Państwa przegrywał spory o własność nieruchomości. Najczęściej miało to miejsce, gdy instytuty prawosławne wykazały warunki nabycia własności w drodze zasiedzenia ${ }^{27}$. Ciekawy był proces o własność nieruchomości klasztornych w Dermaniu. Sprawa po przejściu kilku instancji, włącznie z Sądem Najwyższym, znalazła w 1938 r. rozstrzygnięcie w ponownym orzeczeniu Sądu Apelacyjnego. Wyrok przyznał ostatecznie własność klasztorowi, lecz sąd jednocześnie orzekł o obowiązku zapłaty przez klasztor na rzecz Skarbu Państwa kwoty 200.000 zł tytułem zwrotu równowartości wzniesionego na gruncie budynku. Sąd przyjął, że Skarbowi Państwa przysługiwała specyficzna postać prawa retencji (zatrzymania). Uzasadniono stanowisko względami słuszności i okolicznością, że klasztor nie chciał przyjąć od Skarbu zwrotu wartości gruntu ${ }^{28}$.

\footnotetext{
${ }^{23}$ Dz. Pr. P.P. Nr 21, poz. 67.

${ }^{24}$ SPPG-1931, s. 64-65.

25 SPPG-1933, s. 71.

${ }^{26}$ SPPG-1935, s. 7273.

27 Tamże, s. 73.

28 SPPG-1938, s. 91.
} 
Wzmożona aktywność instytutów prawosławnych na forum sądowym wywołała wiele krytycznych uwag sądów dotyczących braku ustawodawstwa usuwającego niejasność stosunków prawnych i faktycznych Cerkwi. Z tego też powodu Prokuratoria po raz kolejny przedstawiła Ministerstwu Wyznań Religijnych i Oświecenia Publicznego memoriał, w którym podnosiła konieczność niezwłocznej akcji legislacyjnej ${ }^{29}$.

Przedmiotem innych opinii kierowanych do Ministerstwa Wyznań Religijnych i Oświecenia Publicznego, jak też do Ministerstwa Skarbu były sprawy zarządu nieruchomości cerkiewnych. W pismach wyjaśniano treść kompetencji przysługujących państwu z faktu powołania zarządu przymusowego, określano warunki oraz celowość ustanawiania i utrzymywania zarządu ${ }^{30}$. Wielokrotnie Prokuratoria opowiadała się za definitywnym uregulowaniem spraw zarządu przymusowego w drodze ostatecznego zlikwidowania tej instytucji ${ }^{31}$. W piśmie dla Ministerstwa Rolnictwa i Reform Rolnych z 1937 r. Urząd Główny Prokuratorii Generalnej zwrócił uwagę na „konieczność podjęcia kroków zmierzających do usunięcia anormalnego stanu rzeczy jaki się wytworzył w sprawach majątkowych kościoła prawosławnego, gdyż obecnie istnieje taka sytuacja, że z jednej strony wiele majątków przejętych prawomocnie na rzecz Państwa pozostało nadal w posiadaniu poprzednich właścicieli, z drugiej zaś strony setki nieruchomości poklasztornych i pocerkiewnych znajdują się pod zarządem państwowym, mającym z natury rzeczy charakter tymczasowy i wskutek tego pozostają poza wszelkim obrotem, a w szczególności obrotem dla celów reformy ustroju rolnego"32. W 1938 r., po wielu latach prac nad prawnym uregulowaniem pozycji prawnej Kościoła prawosławnego w Polsce, projekt odpowiedniego aktu był gotowy. Urzędowi Głównemu Prokuratorii Generalnej zlecono zaopiniowanie projektu tego dekretu w części dotyczącej własności majątku należącego dawniej do rosyjskiej Cerkwi prawosławnej. Prokuratoria w przedstawionej opinii wyraziła zapatrywanie, że normy regulujące zasady zbycia majątku nieruchomego, uważanego w części za własność Skarbu Państwa, wydane być musiały w drodze ustawodawczej. Konsekwencją stanowiska Prokuratorii było wycofanie z projektu dekretu Prezydenta Rzeczypospolitej odnośnych regulacji, które stać się miały

\footnotetext{
${ }^{29}$ SPPG-1933, s. 72.

30 Tamże.

${ }^{31}$ SPPG-1935, s. 73.

${ }^{32}$ SPPG-1937, s. 78-79.
} 
przedmiotem odrębnej ustawy. Wprowadzono do projektu przepis zapewniający Kościołowi prawosławnemu posiadanie tych majątków, które według projektu ustawy miały przypaść mu na własność. Przepis ów, jak i sam projekt ustawy, ponownie został przesłany do Prokuratorii Generalnej do zaopiniowania. Delegat Prokuratorii przedstawił opinię na dwóch konferencjach zorganizowanych dla ostatecznego zredagowania aktów prawnych $^{33}$. W dniu 18 listopada 1938 r. Prezydent Ignacy Mościcki podpisał dekret o stosunku państwa do Polskiego Autokefalicznego Kościoła Prawostawnego ${ }^{34}$, zaś w dniu 23 czerwca 1939 r. Sejm uchwalił ustawę o uregulowaniu stanu prawnego majątków Kościoła prawosławnego ${ }^{35}$.

\section{SPRAWY KOŚCIOŁÓW EWANGELICKICH W POLSCE}

W sprawach innych wyznań Prokuratoria Generalna podejmowała czynności konsultacyjne w zakresie ich ustroju, stosunków majątkowych i pozycji prawnej. Odnośnie do Kościołów ewangelickich na wzmiankę zasługują takie czynności Prokuratorii, jak opinie z 1923 r. dotyczące kwestii ustrojowych związanych $\mathrm{z}$ ustaniem zależności hierarchicznej polskich kościołów ewangelickich od dotychczasowych naczelnych władz wyznaniowych, które miały obecną siedzibę poza granicami Rzeczypospolitej, czy kwestii dalszego wykonywania funkcji nadzorczych realizowanych dawniej przez Naczelną Radę Kościelną w Wiedniu w odniesieniu do b. zaboru austriackiego oraz dotyczących stosunków prawnych gmin wyznaniowych ewangelickich $^{36}$. W sprawach majątkowych Urząd Główny Prokuratorii Generalnej w 1929 r. wydał opinię, w której uznał, że mimo obowiązywania art. 113 Konstytucji marcowej w odniesieniu do Kościoła ewangelickoaugsburskiego miały w dalszym ciągu moc obowiązującą przepisy zawarte w t. XI Zbioru Praw Cesarstwa Rosyjskiego ustanawiające ograniczenia

${ }^{33}$ SPPG-1938, s. 90-91.

${ }^{34}$ Dz. U. Nr 88, poz. 597.

${ }^{35}$ Dz. U. Nr 57, poz. 370. Istnieje pogląd, że uregulowanie statusu prawnego Kościoła prawosławnego w Polsce zostało przeprowadzone m.in. w celu przygaszenia konfliktu zaostrzonego akcją władz administracyjnych niszczenia na Lubelszczyźnie w 1938 r. licznych obiektów kultu sakralnego. W związku z tymi wydarzeniami Prezes Prokuratorii Generalnej Stanisław Bukowiecki oświadczył w imieniu Skarbu Państwa, że ewentualne roszczenia odszkodowawcze zostaną uznane; za: Borecki 2006, 103.

${ }^{36}$ SPPG-1928, s. 60-61. 
w pozbywaniu i obciążaniu majątku kościelnego ${ }^{37}$. Podobnie w 1935 r. ten sam Urząd Główny Prokuratorii opiniował na gruncie wydanej w 1849 r. w Królestwie Polskim ustawy dla Kościoła ewangelicko-augsburskiego sprawę zezwoleń władz państwowych wymaganych dla poczynienia darowizny na Kościół ${ }^{38}$. W sprawach mających za przedmiot pozycję prawną wyznań ewangelickich w 1935 r. Urząd Główny i Oddział Prokuratorii Generalnej we Lwowie udzielały na wezwanie Ministerstwa Wyznań Religijnych i Oświecenia Publicznego opinii, w których rozważano charakter prawny zborów parafialnych ewangelicko-augsburskich oraz ewangelickohelweckich, jako korporacji prawa publicznego, mających jednocześnie osobowość prawną na gruncie prawa prywatnego, zakres wpływu administracji państwowej na zakładanie i utrzymywanie gmin szkolnych tychże wyznań oraz uprawnień zboru parafialnego $\mathrm{w}$ dziedzinie samoopodatkowania na cele szkolne ${ }^{39}$.

W zakresie czynności sądowych Prokuratoria Generalna prowadziła przede wszystkim procesy przeciwko ewangelickim gminom wyznaniowym o własność i wydanie nieruchomości. Oddział Prokuratorii Generalnej w Poznaniu przez wiele lat toczył spory o uznanie nieważności dokonanych przez ustępujące władze pruskie czynności prawnych przenoszących na gminy ewangelickie własność nieruchomości ${ }^{40}$. Przyczyną sporów prowadzonych w Poznaniu była też nieuregulowana sytuacja prawna Ewangelickiego Kościoła Unijnego w Polsce ${ }^{41}$. W toku jednej ze spraw o uznanie za nieważne przeniesienie własności nieruchomości z powodu dokonania czynności bez zgody państwa, Prokuratoria w Poznaniu podniosła argument, że gminy kościelne Ewangelickiego Kościoła Unijnego nie korzystały w Polsce z uprawnień osób prawa publicznego. Tezę tę wywodzono $\mathrm{z}$ faktu, że Ewangelicki Kościół Unijny nie podporządkował się przepisom rozporządzenia Ministra b. Dzielnicy Pruskiej z 3 lipca 1920 r. zarządzającego przejęcie przez Konsystorz Ewangelicki w Poznaniu kompetencji Ewan-

\footnotetext{
${ }^{37}$ SPPG-1929, s. 47.

${ }^{38}$ Ustawa dla Kościoła ewangelicko-augsburskiego w Królestwie Polskim z 8 (20) lutego 1849 r., Dziennik Praw Królestwa Polskiego Nr 129, T. XLII, s. 11-239; SPPG1935, s. 74.

${ }^{39}$ SPPG-1935, s. 74.

${ }^{40}$ SPPG-1924, s. 86.

${ }^{41}$ SPPG-1936, s. 85.
} 
gelickiej Naczelnej Rady Kościelnej w Berlinie ${ }^{42}$ oraz że nie doszło do zatwierdzenia przez Radę Ministrów zgodnie z rozporządzeniem Prezydenta Rzeczypospolitej z 6 marca 1928 r. ${ }^{43}$ uchwalonego przez Synod Nadzwyczajny statutu Ewangelickiego Kościoła Unijnego ${ }^{44}$. Konsekwencją odmówienia Ewangelickiemu Kościołowi Unijnemu charakteru osoby prawa publicznego było zanegowanie przewidzianego w art. 7 ust. 2 ustawy wykonawczej do niemieckiego kodeksu cywilnego przywileju zwolnienia $\mathrm{z}$ obowiązku uzyskiwania zgody władzy publicznej na nabycie nieruchomości ${ }^{45}$. Ogólną konstatacją tejże sprawy było wyrażenie przez Prokuratorię Generalną opinii o konieczności uregulowania pozycji prawnej Ewangelickiego Kościoła Unijnego. W II Rzeczypospolitej w materii tej podjęto skuteczne działania legislacyjne jedynie w Autonomii Śląskiej. Sejm Śląski w dniu 16 lipca 1937 r. uchwalił ustawę o tymczasowej organizacji Ewangelickiego Kościoła Unijnego na Górnym Ślasku ${ }^{46}$. W prace przygotowawcze nad projektem zaangażowany był Oddział Prokuratorii Generalnej w Katowicach. Przedstawiciele Prokuratorii brali udział w konferencjach zorganizowanych w Śląskim Urzędzie Wojewódzkim. Prokuratoria oficjalnie wydała także opinię prawną o projekcie ustawy ${ }^{47}$.

\section{SPRAWY ŻYDOWSKICH GMIN WYZNANIOWYCH}

Odnośnie wyznania mojżeszowego przykładem czynności Prokuratorii Generalnej była m.in. opinia Oddziału Prokuratorii w Poznaniu z 1924 r. w sprawie likwidacji żydowskich gmin wyznaniowych w b. zaborze pruskim $^{48}$. Zajmowano się też sprawami: dozorów bożniczych i kahałów, które istniały w Królestwie Polskim; specjalnej organizacji i podatków społeczności żydowskiej na Ziemiach Wschodnich Rzeczypospolitej ${ }^{49}$; żydowskich

\footnotetext{
${ }^{42}$ Rozporządzenie Ministra b. Dzielnicy Pruskiej z dnia 3 lipca 1920 r. $w$ sprawie Zjednoczonego Kościoła Ewangelickiego w b. dzielnicy pruskiej, Dz. Urz. Min. b. Dz. Pr. Nr 35, poz. 327.

${ }^{43}$ Rozporządzenie Prezydenta Rzeczypospolitej z dnia 6 marca 1928 r. o zwołaniu Synodu Nadzwyczajnego Ewangelickiego Kościoła Unijnego, Dz. U. Nr 30, poz. 278.

${ }^{44}$ Szerzej zob. Krasowski 1988, 248-51.

${ }^{45}$ SPPG-1937, s. 78.

${ }^{46}$ Dz. U. Śl. Nr 14, poz. 33.

${ }^{47}$ SPPG-1937, s. 77.

${ }^{48}$ SPPG-1928, s. 61.

${ }^{49}$ SPPG-1929, s. 48.
} 
stowarzyszeń pogrzebowych w województwach zachodnich. Na żądanie Ministerstwa Wyznań Religijnych i Oświecenia Publicznego badano relacje tych stowarzyszeń do urzędowej organizacji żydowskich gmin wyznaniowych i ich uprawnień na tle ustawy z dnia 17 marca 1932 r. o chowaniu zamartych $i$ stwierdzaniu przyczyn zgonu oraz sprawy związane $\mathrm{z}$ warunkami likwidacji takich stowarzyszeń ${ }^{50}$. Opiniowano także sprawy opłat pobieranych przez gminy żydowskie, wypowiadając pogląd, że oprócz opłat wyraźnie wymienionych w rozporządzeniu Ministra Wyznań Religijnych i Oświecenia Publicznego z 9 września 1931 r. gminy mogły pobierać także inne opłaty od czynności wykonywanych w zakresie ich ustawowego działania, np. opłaty za miejsca siedzenia w bożnicy, czy za poświadczanie własnoręczności podpisu członka gminy lub w ogóle za wszelkiego rodzaju odpisy, które służyć miały w wewnętrznym obrocie gminy żydowskiej. ${ }^{51}$ W 1934 r. Oddział Prokuratorii Generalnej w Katowicach rozważał charakter prawny wyznaniowych gmin żydowskich, uznając w świetle art. 115 konstytucji marcowej, jak i pruskiej ustawy z dnia 23 lipca 1847 r. o gminach wyznaniowych żydowskich, publicznoprawny charakter tychże gmin. W konsekwencji gminę żydowską uznano za podmiot prawny należący do grupy „władz i urzędów” w rozumieniu § 228 ordynacji pocztowej ${ }^{52}$. W Oddziale lwowskim Prokuratorii Generalnej na żądanie wojewody sporządzono w 1935 r. opinię, w której uzasadniano przejście na Skarb Państwa własności istniejącego dawniej Izraelskiego Funduszu Szkolnego dla Galicji i Bukowiny ${ }^{53}$.

Prezes Prokuratorii Generalnej dodatkowo zaznaczył w jednym ze swoich sprawozdań, że opiniując wiele spraw dotyczących wyznania mojżeszowego Prokuratoria Generalna podkreślała utratę mocy wszelkich aktów prawnych i zwyczajów zobowiązujących społeczność żydowską do świadczenia na rzecz innych wyznań opłat protekcyjnych, homagialnych czy tolerancyjnych $^{54}$. W 1937 r. Urząd Główny Prokuratorii Generalnej rozpatrywał istotę opłaty tzw. „świętalnego”, jaką żydowska gmina wyznaniowa

\footnotetext{
${ }^{50}$ Dz. U. Nr 35, poz. 359; SPPG-1935, s. 74.

${ }^{51}$ Rozporządzenie Ministra Wyznań i Oświecenia Publicznego z dnia 9 września 1931 r. o gospodarce finansowej gmin wyznaniowych żydowskich, Dz. U. z 1931 r. Nr 89, poz. 698; SPPG-1938, s. 90.

${ }^{52}$ Rozporządzenie Ministra Poczt i Telegrafów z dnia 21 marca 1931 r. $w$ sprawie ordynacji pocztowej, Dz. U. Nr 45, poz. 392; SPPG-1934, s. 87.

${ }^{53}$ SPPG-1935, s. 74.

${ }^{54}$ SPPG-1936, s. 86.
} 
płaciła probostwu rzymsko-katolickiemu, a od 1865 r. Skarbowi Państwa jako czynsz z nieruchomości. Prokuratoria Generalna uznała pobieranie takiej opłaty za niedopuszczalne $\mathrm{z}$ powodu jej homagialnego charakteru. ${ }^{55}$

\section{PODSUMOWANIE}

W Polsce okresu dwudziestolecia międzywojennego wprowadzono model scentralizowanej ochrony interesów prawnych i majątkowych państwa oraz innych podmiotów traktowanych w tym zakresie na równi $\mathrm{z}$ państwem. Dekret Tymczasowego Naczelnika Państwa z 7 lutego 1919 r. powoływał Prokuratorię Generalną Rzeczypospolitej Polskiej. Sejm Ustawodawczy utrzymał Prokuratorię w ustroju państwa. Na mocy ustawy opieką prawną Prokuratorii objęto majątki kościołów, przywracając w tej materii rozwiązania w zakresie stosunku państwa do kościołów funkcjonujące w okresie zaborów. Konstytucja Rzeczypospolitej z 1921 r. nadzór państwowy nad wyznaniami znacząco rozluźniała. Zawarcie konkordatu przez Rzeczpospolitą ze Stolicą Apostolską w 1925 r. miało także wpływ na wzrost samodzielności w sferze stosunków wewnętrznych, w szczególności o charakterze majątkowym nie tylko Kościoła katolickiego, lecz również innych kościołów i związków wyznaniowych. Na mocy rozporządzenia Rady Ministrów z 1925 r. zniesiono tutelę Prokuratorii nad kościołami i legalnie działającymi w Polsce związkami wyznaniowymi. Czynności Prokuratorii Generalnej w tej części agendy wyznaniowej, która dotyczyła innych kościołów niż Kościół rzymskokatolicki koncentrowały się na sprawach podmiotowości prawnej tych kościołów, ich ustroju, stosunków majątkowych najczęściej związanych z własnością nieruchomości oraz realizacji obowiązków o charakterze prywatnoprawnym i publicznoprawnym. Aktywność i kompetencje urzędników referendarskich Prokuratorii znacząco wpływały na stosunki wyznaniowe w odrodzonej Polsce.

\section{PIŚMIENNICTWO}

Borecki, Paweł. 2006. „Sytuacja prawna Kościoła prawosławnego w II Rzeczypospolitej." Elpis 8, nr 13/14:93-108.

${ }^{55}$ SPPG-1937, s. 154. 
Buczyński, Krzysztof, i Paweł Sosnowski. 2016. Prokuratoria Generalna. 200 lat tradycji ochrony dobra publicznego, red. nauk. Leszek Bosek. Warszawa: Wydawnictwo Sejmowe.

Krasowski, Krzysztof. 1988. Zwiazki wyznaniowe w II Rzeczypospolitej. Studium historycznoprawne. Warszawa-Poznań: Państwowe Wydawnictwo Naukowe.

Organiściak, Wojciech. 2002. „Utworzenie Prokuratorii Generalnej w II Rzeczypospolitej." Miscellanea Iuridica, t. 1, 141-54.

Sitek, Bronisław. 2014. „Historia ochrony prawnych interesów Skarbu Państwa w Polsce.” Journal of Modern Science 23, nr 4:249-62.

Sitek, Bronisław. 2020. Wybrane systemy prawnej $i$ instytucjonalnej ochrony praw $i$ interesów państwa. Warszawa: Difin.

Tkaczuk, Marek. 2001. „Powstanie Oddziału Prokuratorii Generalnej RP w Poznaniu.” W Przez tysiaclecia: państwo - prawo - jednostka, red. Adam Lityński, i Marian Mikołajczyk, t. 2, 151-60. Katowice: Wydawnictwo Uniwersytetu Śląskiego.

Tkaczuk, Marek. 2006 „Organizacja systemu ochrony i pomocy prawnej Skarbu Państwa w Polsce XX w.” W Podstawy materialne państwa Zagadnienia prawnohistoryczne, red. Daniel Bogacz, i Marek Tkaczuk, 725-37. Szczecin: Wydział Prawa i Administracji US.

Tkaczuk, Marek. 2007. „Akcja Oszczędnościowa i jej wpływ na reorganizację ustroju i zmianę kompetencji Prokuratorii Generalnej Rzeczypospolitej Polskiej w 1924 r.” Studia z Dziejów Państwa i Prawa Polskiego, t. X, 285-302.

Tkaczuk, Marek. 2020. „Sprawy Kościoła katolickiego w praktyce prawnej Prokuratorii Generalnej Rzeczypospolitej Polskiej w dwudziestoleciu międzywojennym.” Teka Komisji Prawniczej PAN Oddziat w Lublinie XIII, nr 2: 515-31.

\section{Sprawy Kościoła prawosławnego, kościołów ewangelickich i gmin wyznaniowych żydowskich w praktyce prawnej Prokuratorii Generalnej Rzeczypospolitej Polskiej w latach 1919-1939}

\section{Streszczenie}

W lutym 1919 r. na mocy dekretu Tymczasowego Naczelnika Państwa Józefa Piłsudskiego utworzono Prokuratorię Generalną Rzeczypospolitej Polskiej. Sejm Ustawodawczy uchwaloną w lipcu 1919 r. ustawą utrzymał w ustroju państwa Prokuratorię i scentralizowany model ochrony interesów prawnych i majątkowych państwa. Sejm Ustawodawczy powierzył Prokuratorii także ochronę interesów majątkowych kościołów. Ochrona Prokuratorii przyjmowała postać pomocy prawnej w drodze zastępstwa prawnego lub czynności konsultacyjnych albo opiniodawczych. Ochrona Prokuratorii, traktowana przez kościoły jako forma nadzoru państwowego, została zniesiona w $1926 \mathrm{r}$. Agendę prowadzoną przez Prokuratorię po 1925 r. w kategorii określanej jako sprawy wyznaniowe wypełniały czynności zmierzające do ochrony interesów publicznych i majątkowych państwa w stosunkach z kościołami i innymi związkami religijnymi.

Słowa kluczowe: Skarb Państwa; zastępstwo prawne; ochrona prawna interesów publicznych i majątkowych 


\title{
The Affairs of the Orthodox Church, Evangelical Churches and Jewish Religious Communities in the Legal Practice of the General Counsel's Office of the Republic of Poland in the Years 1919-1939
}

\begin{abstract}
Summary
The General Counsel's Office of the Republic of Poland came into existence be a decree of the temporary Chief of State Józef Piłsudski on 7 February 1919. Six months later, on 31 July 1919, the Polish parliament revoked the decree and passed a new law establishing a centralized model for the protection of the legal and property interests of the state and churches. Protection afforded by the General Counsel's Office of the Republic of Poland had the form of legal representation and legal opinions. This protection, regarded by the churches as a form of state's supervision, was abolished in 1926. After 1925 the affairs of the Orthodox Church, Evangelical Churches, and Jewish religious communities were narrowed down to the protection of the state's public and property interests in relation to the churches.
\end{abstract}

Keywords: the State Treasury; legal representation; legal protection of public and property interests

Information about Author: DR. HABIL. MAREK TKACZUK - Faculty of Law and Administration, the University of Szczecin; correspondence address: ul. Narutowicza 17A, 70-240 Szczecin, Poland; e-mail: marek.tkaczuk@usz.edu.pl; https://orcid.org/00000001-9511-813x 